\title{
Pengembangan Profesionalisme Guru Melalui Model Lesson Study
}

\author{
C. Rudy Prihantoro \\ Fakultas Teknik Universitas Negeri Jakarta
}

\begin{abstract}
Abstrak: Lesson study (LS) adalah sebuah proses pengembangan kompetensi keprofesionalan guru secara sistematis yang bertujuan untuk menjadikan proses pembelajaran lebih baik dan efektif. Tahapan LS yaitu Plan, Do, See. LS mensyaratkan stabilitas kebijakan pendidikan, kurikulum fleksibel, budaya refleksi diri dan kerjasama. Kelebihan LS adalah berorientasi pada siswa, bekerja sebagai tim, mengembangkan teknik mengajar. Pengembangan LS dalam profesionalime guru yaitu merencanakan tujuan pembelajaran dan materi pokok; mengkaji dan mengembangkan pembelajaran; memperdalam penge-tahuan yang diajarkan; memikirkan tujuan jangka panjang siswa; merancang pembelajaran kolaboratif; mengkaji proses belajar, perilaku dan hasil belajar siswa; dan, mengembangkan pedagogis. LS dilaksanakan dengan membentuk kelompok LS, memfokuskan LS, Merencanakan Research Lesson $(\mathrm{RL})$, membelajarkan dan mengamati $\mathrm{RL}$, mendiskusikan dan menganalisis $\mathrm{RL}$, serta merefleksikan dan merencanakan kembali LS. Manfaat LS diantaranya memicu munculnya motivasi untuk mengembangkan diri, melatih pendidik "melihat" peserta didik, menjadikan penelitian sebagai bagian integral pendidikan, penyebaran inovasi dan pendekatan baru, menempatkan para pendidik pada posisi terhormat.
\end{abstract}

Kata Kunci : Lesson study, Implementasi, Profesionalisme

\begin{abstract}
Lesson study (LS) is a competence development process in a systematic teacher professionalism which aims to make learning better and more effective. Stages LS ie Plan, Do, See. LS requires the stability of education policy, curriculum, flexible, self-reflection and cultural cooperation. Excess LS is oriented to students, working as a team, developing a teaching technique. LS development in the professionalism of teachers is to plan learning objectives and subject matter, review and develop learning; deepen knowledge that is taught; thinking about long-term goals of students; designing collaborative learning; examines the process of learning, behavior and student learning outcomes, and, develop pedagogical. LS carried out by forming groups of LS, LS focus, Planning the Research Lesson (RL), RL teach and observe, discuss and analyze the RL, as well as reflect and plan for re-LS. LS Benefits include triggering the emergence of self-motivation to develop, train educators to "see" the learner, making research an integral part of education, dissemination of innovation and new approaches, puts educators in a respectable position.
\end{abstract}

Key words: lesson study, Implementation, professionalism

\section{Pendahuluan}

Pendidikan di Indonesia hingga saat ini masih banyak diperdebatkan oleh berbagai kalangan pemerhati pendidikan. Kesenjangan pemerataan pendidikan masih menjadi fakta yang ditemukan diberbagai pelosok wilayah Indonesia, dengan berbagai kendala yang muncul ke permukaan dan menjadi isu hangat tentang pendidikan di Indonesia.

Posisi Indonesia yang menduduki peringkat ke-110 dari 177 negara yang dilaporkan oleh UNDP pada tahun 2005 cukup memprihatinkan bagi banyak kalangan yang berusaha mencari akar permasalahan yang menyebabkan kualitas pendidikan di Indonesia dilaporkan berada di bawah negara tetangga seperti Singapura (ranking 25), Brunei Darusalam (ranking 33), Malaysia (rangking 61), Thailand (ranking 73), Philipina (ranking 84) dan Vietnam (ranking 108). Pendapat beberapa pemakalah dalam berbagai kesempatan membicarakan tentang kualitas pendidikan telah lama dikemukakan bahwa kualitas pendidikan di Indonesia masih sangat rendah tingkat kompetisi dan relevansinya (Parawansa, 2001; Suyanto, 2001; Siskandar, 2003). Walaupun banyak upaya telah dilakukan Pemerintah Indonesia untuk memperbaiki kualitas pendidikan diantaranya adalah melakukan perubahan atau revisi 
kurikulum, program kemitraan, peningkatan kualifikasi guru dan dosen, sertifikasi guru dan dosen, dan masih banyak program lain dilakukan, tetapi upaya tersebut belum menunjukkan hasil yang signifikan. Upaya perbaikan pendidikan tampaknya masih belum seutuhnya memperhatikan konsepsi belajar dan pembelajaran yang seyogyanya dimulai dari bagaimana siswa dan guru belajar dan bagaimana guru mengajar, bukan semata-mata pada hasil belajar (Brook \& Brook, 1993). Senada dengan yang dikemukakan oleh Podhorsky \& Moore (2006) menyatakan, bahwa perbaikan pendidikan hendaknya dimaknai sebagai upaya penciptaan program-program yang berfokus pada perbaikan praktik mengajar dan belajar, bukan semata-mata berfokus pada perancangan kelas dengan menyampaikan kurikulum apa adanya.

Guru seyogyanya lebih menciptakan programprogram pengembangan yang profesional dengan memanfaatkan fasilitas yang dapat memberi peluang kepada mereka learning how to learn dan to learn about teaching, misalnya dengan memfasilitasi guru mengembangkan Lesson Study (LS) atau kaji pembelajaran.

LS menyediakan suatu cara bagi guru untuk dapat memperbaiki pembelajaran secara sistematis (Podhorsky \& Moore, 2006). LS menyediakan suatu proses untuk berkolaborasi dan merancang pembelajaran dan mengevaluasi kesuksesan strategi-strategi mengajar yang telah diterapkan sebagai upaya meningkatkan proses dan perolehan belajar siswa. Penggunaan proses LS dengan program-program pengembangan yang profesional tersebut merupakan wahana untuk mengembalikan guru kepada budaya mengajar yang proporsional (Lewis \& Tsuchida, 1998).

Para guru banyak yang belum mengetahui tentang LS, bagaimana pengimplementasian LS dalam proses belajar mengajar sehubungan dengan pengembangan profesionalisme guru dan apa manfaat LS yang dapat diperoleh.

Penulisan ini bertujuan untuk mengkaji pengembangan keprofesionalan guru melalui implementasi model LS dalam proses pembelajaran yang lebih baik dan efektif sesuai dengan konteks LS yang disesuaikan dengan kondisi di Indonesia, sehingga guru dapat memfasilitasi siswa memiliki perilaku yang berbudaya dan meningkatkan hasil belajarnya. Diharapkan dengan pengembangan keprofesionalan guru melalui berbagai metode pengajaran, salah satunya adalah LS, kualitas pendidikan di Indonesia dapat menyumbangkan tingkat kualitas kehidupan bangsa Indonesia secara signifikan.

\section{Kajian Literatur Pengertian Lesson Study (LS)}

LS adalah sebuah proses pengembangan kompetensi profesional untuk para guru yang dikembangkan secara sistematis dengan tujuan utama menjadikan proses pembelajaran lebih baik dan efektif (Cerbin dan Kopp, 2006).

Menurut Stigler dan Hiebert (1999), LS umumnya mengikuti 8 langkah utama, yaitu: 1) mendefinisikan permasalahan, hal ini dapat berlaku secara umum, misalnya bagaimana membuat peserta didik menyukai pelajaran fisika, atau permasalahan khusus, misalnya bagaimana membuat peserta didik memahami Teori Relativitas Einstein; 2) merencanakan proses belajar mengajar (PBM), proses ini dilakukan secara bersama-sama dan kolaboratif antar anggota kelompok, denga tujuan untuk mencari solusi terbaik dari permasalahan; 3) melaksanakan PBM, proses ini dilaksanakan oleh salah seorang guru sementara anggota lainnya berperan sebagai observer yang mencatat perilaku peserta didik dan hal-hal yang terjadi selama PBM; 4) melakukan diskusi dan refleksi terhadap proses PBM yang baru dilakukan, kegiatan ini bertujuan melakukan evaluasi terhadap proses PBM terutama pada penerapan alternatif solusi permasalahan, 5) melakukan revisi terhadap rencana PBM, dari hasil refleksi para anggota kelompok kembali bekerja bersama untuk membuat rencana PBM yang bisa memberikan hasil lebih baik daripada sebelumnya; 6) melaksanakan PBM kembali untuk mencoba rencana PBM yang baru disusun, pada tahap ini dapat juga diundang observer dari luar untuk memberikan pendapat dan saran bagi pengembangan solusi lebih lanjut; 7) evaluasi dan refleksi lebih lanjut untuk kembali membahas berbagai hasil dari penerapan solusi pada PBM yang telah dilaksanakan; dan 8) membagi hasil pengalaman tersebut dalam bentuk diskusi atau publikasi berupa tulisan. 
Walaupun demikian ke-8 langkah ini tidak bersifat mutlak harus diikuti karena beberapa versi menggunakan jumlah tahapan yang berbeda namun dengan substansi yang pada umumnya sama. Secara lebih sederhana, tahapan LS dapat dilakukan melalui serangkaian kegiatan: PlanningDoing-Seeing (Saito, et al., 2005). Ketiga kegiatan tersebut diistilahkan sebagai kaji pembelajaran berorientasi praktik. Kegiatan-kegiatan tersebut dilukiskan seperti pada Gambar 1.
Lebih lanjut, Lewis menyatakan, bahwa LS adalah suatu proses yang kompleks, didukung oleh penataan tujuan secara kolaboratif, percermatan dalam pengumpulan data tentang belajar siswa, dan kesepakatan yang memberi peluang diskusi yang produktif tentang isu-isu yang sulit. LS pada hakikatnya merupakan aktivitas siklikal berkesinambungan yang memiliki implikasi praktis dalam pendidikan. Siklus LS disajikan pada Gambar 2.

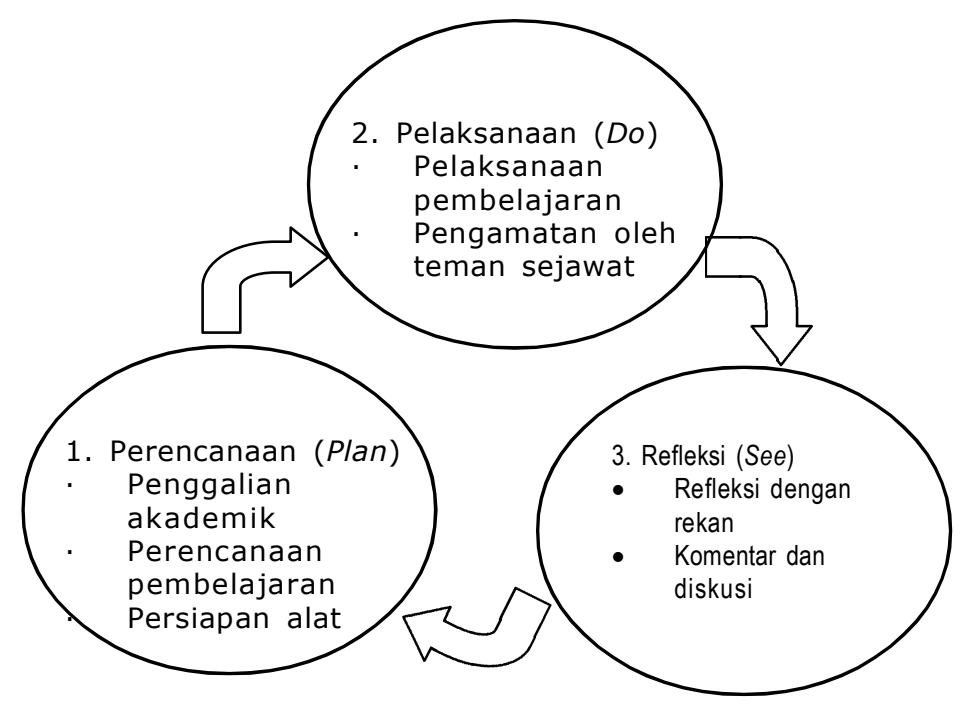

Gambar 1. Daur Kaji Pembelajaran Berorientasi Praktik

1. Goal Setting And Planning

Mengidentifikasi tujuan belajar siswa, pengembangan jangka panjang siswa,

menyusun perencanaan pembelajaran yang meliputi research lesson yang dipantau secara berkolaboratif.
2. Research Lesson

Salah seorang guru melaksanakan pembelajaran berdasarkan pembelajaran yang disusun, sedangkan guru lain mengamati dan mengumpulkan data tentang belajar siswa, berpikir tentang perilaku siswa, dll.

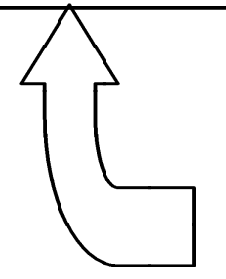

4. Consolidation of Learning

Menulis laporan yamng mencakup perencanaan pembelajaran,

data hasil pengamatan siswa dan melakukan refleksi tehadap

pembelajaran yang dilaksanakan. Melakukan perancangan ulang seperlunya.

Gambar 2. Siklus Lesson Study 


\section{Perkembangan Lesson Study}

LS tidak bisa dilepaskan dari Kounaikenshu Jepang yaitu sebuah bentuk CPD (Continuing Professional Development) (Fletcher, 2005). Kounaikenshu mulai berkembang pada tahun 1960-an adalah bentuk pelatihan berkelanjutan berbasis sekolah (schoolbased in service training) (Hendayana, 2007), dimana setiap guru secara terus-menerus melakukan workshop bersama rekan-rekannya untuk meningkatkan kualitas profesional mereka.

Kounaikenshu muncul sebagai jawaban atas berbagai permasalahan yang muncul di berbagai sekolah di Jepang antara lain bullying (intimidasi oleh teman), penolakan siswa untuk pergi ke sekolah, penurunan prestasi dan sebagainya. Pemerintah Jepang melihat bahwa Kounaikenshu bisa menjadi solusi alternatif untuk berbagai permasalahan tersebut sehingga diluncurkan sejumlah program dengan berbagai insentif agar sekolah-sekolah membentuk kelompok-kelompok Kounaikenshu.

Setelah banyak memperoleh keberhasilan dan melalui berbagai evolusi Kounaikenshu pada tahun 90-an berkembang menjadi jugyou kenkyuu, yang apabila diterjemahkan secara bebas jugyou berarti pelajaran atau lesson dan kenkyuu berarti riset (Lewis, 2000). Jugyou kenkyuu yang dipopulerkan oleh Prof. Manabu Sato, melepaskan ketergantungan dari guru dan kurikulum yang kaku, membawa guru dan siswa menjadi lebih aktif dan memiliki visi lebih luas, serta memberikan ruang bagi munculnya sebuah solusi pembelajaran yang bersifat aplikatif. Perubahan ini adalah penciptaan masyarakat belajar di sekolah dan membuka seluas-luasnya proses pembelajaran di kelas untuk diamati oleh siapa saja.

Jugyou kenkyuu merupakan sebuah ide sederhana untuk memperbaiki pengajaran yang lebih nyata dari sekedar sebuah kolaborasi antara guru dengan guru sejawat lain untuk merencanakan, mengajar, mengobservasi, meninjau kembali dan melaporkan hasilnya pada aplikasi dalam pengajaran individu. Istilah LS sendiri dimunculkan pertama kali oleh Makoto Yoshida, seorang pakar pendidikan Jepang pada disertasi doktoralnya di University of Chicago, dengan menerjemahkan jugyou kenkyuu sebagai Lesson Study. Bersama Catherine Lewis seorang profesor pendidikan dari Mills College Oakland, LS semakin mendapat tempat di Amerika sejak adanya perhelatan The Third International Mathematics and Science Study (TIMSS) yang merupakan studi untuk membandingkan pencapaian hasil belajar Matematika dan IPA kelas 8 pada tahun 1995 . Setelah melakukan berbagai penelitian mereka menyadari bahwa ketertinggalan tersebut sebagian besar disebabkan oleh tidak adanya peningkatan mutu berkelanjutan baik terhadap pendidik maupun kualitas pembelajaran di Amerika (Hendayana, 2007).

Pada awalnya penerapan ini mengundang berbagai nada pesimis, sebagian besar praktisi pendidikan di Amerika menganggap LS hanya cocok diterapkan di Jepang dan tidak sesuai untuk kondisi di Amerika. Walaupun demikian pada perkembangannya mulai banyak sekolah dan bahkan perguruan tinggi yang mencoba menerapkan LS terutama untuk mata pelajaran/ mata kuliah sains semacam matematika dan fisika. Sebuah fakta menarik adalah penerapan LS di Amerika justru lebih berkembang di perguruan tinggi daripada di tingkat sekolah.

Di Indonesia sendiri LS berkembang melalui proyek IMSTEP (Indonesia Mathematics and Science Teacher Education Project), yaitu sebuah proyek kerjasama antara tiga perguruan tinggi di Indonesia dengan JICA (Japan International Corporation Agency) untuk meningkatkan mutu pendidikan matematika dan IPA di Indonesia (Hendayana, 2007).

\section{Implementasi Lesson Study}

LS sebagai sebuah inovasi tidak akan mudah untuk diterapkan tanpa berbagai kendala. Dukungan untuk terciptanya kondisi ideal menjadi sangat penting terutama untuk meyakinkan para pendidik bahwa LS akan memberikan manfaat optimal bagi mereka. Dengan mengambil sebagian pelajaran dari Jepang, kita berharap LS dapat diterapkan secara optimal di Indonesia.

Kondisi ideal yang mendukung suksesnya 
penerapan lesson study, yaitu:

\section{Stabilitas kebijakan pendidikan}

Kebijakan bidang pendidikan perlu dilakukan secara hati-hati. Inovasi diterapkan secara hatihati melalui evaluasi yang cermat. Dengan stabilitas kebijakan maka pendidik dapat berkonsentrasi pada tugasnya dan tidak perlu memikirkan kebijakan yang justru kontra produktif. Jika terlalu banyak perubahan kebijakan, akan menyebabkan pendidik tidak dapat memusatkan perhatian kepada tanggungjawabnya dalam memberikan pengetahuan kepada peserta didik.

\section{Kurikulum yang fleksibel}

Kurikulum dibuat dengan materi yang tidak terlalu banyak, hal ini memberi kesempatan kepada para pendidik memiliki waktu lebih banyak untuk memberikan pengertian kepada para siswa dari setiap materi yang diberikan. Buku pelajaran tidak perlu tebal, sehingga akan memberi ruang yang menuntut para guru untuk berpikir dan mengembangkan materi sendiri. Hal ini memaksa para pendidik mendiskusikan dengan rekanrekannya dalam rangka mengembangkan konten materi tersebut.

\section{Budaya refleksi diri}

Seyogyanya menjadi budaya bagi para pendidik untuk selalu melakukan kritik terhadap diri sendiri apabila mereka tidak berhasil menjalankan tanggungjawabnya. Pada era modern budaya ini dapat dikembangkan menjadi sebuah budaya positif, yaitu selalu merefleksi diri terhadap kondisi-kondisi yang terjadi. Hal ini diharapkan para pendidik selalu berusaha mencari sebab kegagalan dari diri sendiri terlebih dahulu dan memperbaikinya agar tidak terulang dikemudian hari.

\section{Budaya kerjasama}

Seseorang yang mampu membantu rekanrekannya untuk mencapai kesuksesan bersamasama akan lebih terhormat daripada yang memiliki karir cemerlang tetapi mencapainya seorang diri, meski hal ini dipandang aneh oleh budaya yang cenderung berkembang saat ini. Budaya kerjasama inilah yang menyebabkan LS dapat dengan mudah berkembang dan akan dapat diterima dikalangan pendidikan dikarenakan kerjasama antar pendidik adalah salah satu hakekat dari LS.

Menurut Cerbin dan Cobb, ada 4 alasan utama yang memotivasi penggunaan LS yaitu untuk: 1) memahami lebih baik bagaimana peserta didik memahami apa yang diajarkan; 2) menciptakan produk yang bisa digunakan oleh pendidik lain dikelompoknya; 3) memperbaiki cara mengajar; dan 4) membentuk pengetahuan pedagogis yang berdasar pada manfaat apa yang dapat guru terima sebagai pengetahuan lain dalam mengajar.

LS pada dasarnya adalah pembelajaran kelas secara klasikal dengan beberapa karakteristik khusus, antara lain: 1) Pembelajaran dalam LS diobservasi oleh tutor atau guru lain. Guru atau tutor yang melakukan observasi dapat berasal dari lembaga yang sama atau grup yang lebih luas, bahkan beberapa pembelajaran LS membuka kesempatan bagi guru yang berasal dari negara lain untuk melakukan observasi; 2) LS direncanakan untuk pembelajaran dalam waktu lama dan biasanya bersifat kolaborasi; 3) LS didesain untuk memberikan pengertian tentang tujuan atau visi dari suatu proses pendidikan; 4) LS harus terdokumentasi dengan baik; dan 5) LS adalah untuk didiskusikan.

Tipe paling umum dari LS adalah "within school research lesson", yang pada umumnya model LS ini mengambil tempat di sekolah. Tipe kedua adalah "public research lesson", model tipe ini terbuka untuk para guru dari luar sekolah, baik dikelola oleh kelompok guru dalam wilayah daerah ataupun oleh pemerintah daerah atau pusat. Tipe lainnya adalah LS sebagai bagian dari konferensi nasional atau asosiasi guru.

\section{Profesionalisme Guru}

Profesionalisme merupakan mutu dan tindak tanduk yang bercirikan suatu profesi. Profesi itu sendiri mengandung makna bidang pekerjaan yang dilandasi pendidikan keahlian tertentu. Menurut Mc Cully (dalam A.Tabrani Rusyan 1992) mengatakan "Profession is a vocation an wich profesional knowledge of some departement a learning science is used in its application to the of other or in the practice of an art found it". 
Dari pengertian tersebut dapat ditafsirkan bahwa dalam suatu pekerjaan yang bersifat profesional menggunakan teknik serta prosedur yang bertumpu pada landasan intelektual, yang sengaja harus dipelajari dan kemudian secara langsung dapat diabadikan bagi permasalahan orang lain.

Profesionalisme diartikan sebagai kualitas atau tindak tanduk yang merupakan ciri suatu bidang pekerjaan dengan dilandasi pendidikan keahlian (keterampilan, kejuruan) tertentu untuk menjalankannya. Menurut Nana Sudjana (dalam M. Uzer Usman. 2002) mengatakan pekerjaan yang bersifat profesional adalah: "pekerjaan yang hanya dapat dilakukan oleh mereka yang khusus dipersiapkan untuk itu dan bukan pekerjaan yang dilakukan oleh mereka yang karena tidak dapat memperoleh pekerjaan lain".

Freidson (dalam Syaiful Sagala, 2000) menjelaskan bahwa "profesionalisme adalah sebagai komitmen untuk ide-ide profesional dan karir". Profesionalisme memiliki aturan dan komitmen untuk memberi definisi jabatan keilmuan teknik dan jabatan yang akan diberikan pada pelayanan masyarakat agar secara khusus pandangan-pandangan jabatan dikoreksi secara keilmuan dan etika sebagai pengukuhan terhadap profesionalisme. Profesionalisme tidak dapat dilakukan atas dasar perasaan, kemauan, pendapat, tetapi benar-benar dilandasi oleh pengetahuan secara akademik.

Lebih lanjut Paure (dalam Syaiful Sagala, 2000), mengatakan bahwa "profesionalisme harus mereduksi lama pendidikan untuk memberikan kualifikasi bagus tanpa mengurangi standar dengan metodologi pengajaran yang tepat, percepatan proses belajar, menyeleksi ilmu yang diberikan, mengkombinasikan studi dengan pekerjaan secara langsung dalam fase-fase yang terintegrasi".

Tenaga pendidik profesional ialah mereka yang menguasai substansi pekerjaannya secara profesional. Guru yang profesional menurut Nanang Fattah (2004) adalah: a) mampu menguasai substansi mata pelajaran secara sistematis, khususnya materi pelajaran yang secara khusus diajarkannya dan dituntut untuk berupaya mengikuti perkembangan materi pelajaran tersebut dari waktu ke waktu; b) memahami dan dapat menerapkan psikologi perkembangan sehingga seorang guru dapat memilih materi pelajaran berdasarkan tingkat kesukaran sesuai dengan masa perkembangan peserta didik yang diajarkan; dan c) memiliki kemampuan mengembangkan program-program pendidikan yang secara khusus disusun sesuai dengan tingkat perkembangan peserta didik yang akan diajarnya. Program pendidikan ini dikembangkan sesuai dengan tujuan pendidikan dengan mengkombinasikan antara pilihan materi pelajaran, tingkat perkembangan peserta didik. Keahlian dalam mengembangkan program pengajaran inilah yang bisa kita identifikasikan sebagai pekerjaan profesional seorang guru yang tidak bisa dilakukan oleh profesi lain.

Tenaga pendidik yang profesional akan mampu menterjemahkan kapasitas profesional mereka sendiri ke dalam pekerjaan atau profesinya, yaitu membelajarkan siswa. Demikian juga seorang tenaga pendidik harus terus berupaya meningkatkan kompetensinya dalam mengelola proses belajar mengajar.

Guru sebagai tenaga pendidik wajib memiliki kualifikasi akademik, kompetensi, sertifikat pendidik, sehat jasmani dan rohani, serta memiliki kemampuan untuk mewujudkan tujuan pendidikan nasional. Kompetensi dasar yang harus dimiliki guru meliputi kompetensi paedagogik, kompetensi personal atau kepribadian, kompetensi sosial, dan kompetensi profesional yang diperoleh melalui pendidikan profesi (UU No.14 Th. 2005). Suparno, (2005) mengatakan kompetensi ini, berkaitan dengan kemampuan guru dalam mengajar, membimbing, dan juga memberikan teladan hidup kepada siswa. Berdasarkan hasil penelitian, banyak guru kita masih rendah dalam kompetensi pengajaran, maka dalam pendidikan profesi dan sertifikasi kemampuan keterampilan mengajar harus diutamakan.

\section{Pengembangan Profesionalisme Guru melalui Lesson Study}

LS dapat memberi solusi, karena $L S$ adalah model pembinaan profesi pendidik melalui pengkajian pembelajaran secara kolaboratif dan berkesinambungan berlandaskan prinsip-prinsip kolegalitas dan mutual learning untuk membangun komunitas belajar. Para pendidik secara kolaboratif, pertama-tama menganalisis masalah 
pembelajaran, baik dari aspek materi ajar maupun metode pembelajaran. Selanjutnya secara kolaboratif pula para pendidik mencari solusi dan merancang pembelajaran yang berpusat pada siswa. Langkah berikutnya adalah menerapkan pembelajaran dikelas oleh seorang guru, sementara yang lain sebagai pengamat aktivitas siswa yang dilanjutkan dengan diskusi pasca pembelajaran untuk merefleksikannya. Jika prinsip-prinsip $L S$ ini dilakukan secara sistemik dan berkelanjutan dimungkinkan akan berdampak pada peningkatan mutu pendidikan di Indonesia.

LS merupakan salah satu strategi pengembangan profesi guru. Kelompok guru mengembangkan pembelajaran secara bersama-sama, salah seorang guru ditugasi melaksanakan pembelajaran, guru lainnya mengamati belajar siswa. Proses ini dilaksanakan selama pembelajaran berlangsung. Pada akhir kegiatan, guru-guru berkumpul dan melakukan tanya jawab tentang pembelajaran yang dilakukan, merevisi dan menyusun pembelajaran berikutnya berdasarkan hasil diskusi.

LS dalam pengembangan profesionalisme guru, ada 8 (delapan) peluang yang dapat diperoleh apabila dia melaksanakan secara berkesinambungan. Ke-8 peluang tersebut sangat erat kaitannya dengan pengembangan profesionalisme guru (Lewis, 2002), yaitu: 1) memikirkan dengan cermat mengenai tujuan pembelajaran, materi pokok, dan bidang studi; 2) mengkaji dan mengembangkan pembelajaran yang terbaik yang dapat dikembangkan; 3 ) memperdalam pengetahuan mengenai materi pokok yang diajarkan; 4) memikirkan secara mendalam tujuan jangka panjang yang akan dicapai yang berkaitan dengan siswa; 5) merancang pembelajaran secara kolaboratif; 6) mengkaji secara cermat cara dan proses belajar serta tingkah laku siswa; (7) mengembangkan pengetahuan pedagogis yang kuat penuh daya; dan (8) melihat hasil pembelajaran sendiri melalui siswa dan kolega.

Oleh karena LS dapat meningkatkan profesionalisme guru, maka pelaksanaan LS secara berkesinambungan diyakini dapat meningkatkan praktik-praktik pembelajaran sehari-hari. Peningkatan praktik-praktik pembelajaran akan bermuara pada peningkatan kualitas proses dan produk belajar siswa. Dalam praktik pembelajaran, secara operasional LS dapat dilaksanakan melalui 6 (enam) tahapan, yaitu: 1) membentuk kelompok LS; 2) mefokuskan LS; 3) Merencanakan Research Lesson (RL); 4) membelajarkan dan mengamati RL; 5) mendiskusikan dan menganalisis RL; dan 6) merefleksikan dan merencanakan kembali LS.

\section{Simpulan dan Saran Simpulan}

LS merupakan alternatif pembinaan profesi guru melalui aktivitas kolaboratif dan berkelanjutan. Prinsip kolaborasi akan memfasilitasi para guru untuk membangun komunitas belajar yang efektif dan efesien, sedangkan prinsip berkelanjutan akan memberi peluang bagi guru untuk menjadi masyarakat belajar sepanjang hayat.

Implementasi LS secara berkelanjutan akan membantu guru mengembangkan kompetensi profesional dan mempercepat peningkatan profesionalismenya. Indikator-indikator peningkatan profesionalisme guru melalui implementasi LS adalah pengembangan Rancangan dan Pelaksanaan Pembelajaran (RPP) yang selalu menuntut dilakukannya inovasi pembelajaran dan asesmen, siklus plan-do-see yang memungkinkan guru untuk dapat mengembangkan pemikiran kritis dan kreatif tentang belajar dan pembelajaran, proses sharing pengalaman berbasis pengamatan pembelajaran memberi peluang bagi guru untuk mengembangkan keterbukaan dan peningkatan kompetensi sosialnya, dan proses refleksi secara berkelanjutan adalah suatu ajang bagi guru untuk meningkatkan kesadaran akan keterbatasan dirinya.

LS dapat diimplementasikan dalam pembelajaran melalui siklus plan-do-see dengan enam tahapan, yaitu membentuk kelompok LS, menentukan fokus kajian, merencanakan research lesson, pelaksanaan pembelajaran dan observasi aktivitas pembelajaran, mendiskusikan dan menganalisis hasil observasi, dan refleksi dan penyempurnaan. Tahapan-tahapan kegiatan LS tersebut dapat memfasilitasi peningkatan kualitas proses pembelajaran dan hasil belajar siswa menjadikan proses pembelajaran lebih baik dan efektif. 


\section{Saran}

Aktivitas LS membutuhkan pengorbanan dari segi waktu untuk para pendidik. Dengan melakukan perencanaan dan menggunakan pendekatan yang terarah dan mudah dipahami oleh anggota kelompok LS maka konsumsi waktu untuk melakukan LS dapat diminimalkan.

LS berfokus pada pendidik dan cara belajar peserta didik, seiring dengan meningkatnya aktivitas LS akan berimplikasi pada meningkatnya kualitas peserta didik. Sehingga mengukur keberhasilan LS tidak semata-mata hanya dari hasil tes atau ujian peserta didik.

LS bukan tentang mencari gaya mengajar siapa yang paling baik diantara anggota kelompok. LS bertujuan mencari cara mengajar yang paling baik dengan mengkolaborasikan berbagai kelebihan dari para pendidik yang menjadi anggota kelompok. Hal penting dalam lesson studi ini adalah keinginan masing-masing anggota kelompok untuk berkembang menjadi lebih baik.

LS lebih banyak menuntut tindakan nyata daripada berbicara masalah konseptual. Berdiskusi justru merupakan contoh nyata dari tindakan tersebut apabila arah diskusi diperjelas sesuai dengan substansi pembahasan.

Dokumentasi adalah salah satu prinsip dasar dalam aktivitas kelompok lesson study. Catatancatatan diskusi dan observasi dibutuhkan antara lain guna mencegah pengulangan topik diskusi yang sama dan mencatat hasil pengamatan terhadap perilaku peserta didik selama proses PBM.

\section{Pustaka Acuan}

Brooks, J. G., \& Brooks, M. G. 1993. In search of understanding: The case for constructivist classrooms. Virginia: Association for Supervision and Curriculum Development.

Cerbin, B., \& Kopp B. (2006, April) Lesson study: Building the scholarship of teaching and learning one lesson at a time. Paper presented at the 2006 CASTL Colloquium on the Scholarship of Teaching and Learning, Madison WI. Retrieved June 29, 2006 from http://lessonstudy.blogs. com/college/2006/06/lesson study th.html

Fattah, Nanang. 2004. Landasan manajemen pendidikan. Bandung: Remaja Rosda Karya.

Fletcher, S. (2005) Using Digital Technology for Practitioner Research, in Research Intelligence, The British Educational Research Association.

Hendayana, Sumar. 2006. Lesson Study Suatu Strategi Untuk Meningkatkan Keprofesionalan Pendidikan (Pengalaman IMSTEP-JICA). Bandung: UPI Press.

Human Development Report 2005, International cooperation at a crossroads: Aid, trade and security in an unequal world. Published for the United Nations Development Programme (UNDP) Copyright (C) 2005 by the United Nations Development Programme 1 UN Plaza, New York, New York, 10017, USA.

Lewis, Catherine.2000. Lesson Study: The Core of Japanese Professional Development. New Orleans: Invited Address to the Special Interest Group on Research in Mathematics Education American Educational Research Association Meetings.

Parawansa, P. 2001. Reorientasi Terhadap Strategi Pendidikan Nasional. Makalah. Disajikan dalam Simposium Pendidikan Nasional dan Munas I Alumni PPs UM di Malang, 13 Oktober 2001.

Podhorsky, C. \& Moore, V. 2006. Issues in curriculum: Improving instructional practice through lesson study. Tersedia pada http://www.lessonstudy.net.

Sagala, Syaiful, 2000. Manajemen dan Kebijakan Otonomi Pendidikan Untuk Pemberdayaan Masyarakat, Makalah, PPS, UPI, Bandung.

Saito, E., Harun, I., Kuboki, I., and Tachibana, H. (2006). Indonesian Lesson Study in Practice: Case Study of Indonesian Mathematics and Sciemce teacher Education Project. Journal of In Service Education.

Siskandar. 2003. Teknologi Pembelajaran Dalam Kurikulum Berbasis Kompetensi. Makalah. Disajikan pada Seminar Nasional Teknologi Pembelajaran pada tanggal 22-23 Agustus 2003 di Hotel Inna Garuda Yogyakarta. 
Stigler, J., \& Hiebert, J. 1999. The Teaching Gap: Best Ideas from the World's Teachers for Improving Education in the Classroom. New York: Summit Books.

Suparno, Paul, 2005, Dampak RUU Guru Terhadap Kualitas dan Kesejahteraan Guru, Kedaulatan Rakyat, 15/11/2005, Yogyakarta.

Suyanto. 2001. Formula Pendidikan Nasional Era Global. Makalah. Disajikan dalam Simposium Pendidikan Nasional dan Munas I Alumni PPs UM di Malang, 13 Oktober 2001.

Tabrani Rusyan. 1992. Profesionalisme tenaga kependidikan. Jakarta: Nine Karya Jaya.

Usman, Muhammad Uzer. 2002. Menjadi Guru Profesional. Bandung : Remaja Rosda Karya.

Undang-Undang Republik Indonesia Nomor 14 Tahun 2005 Tentang Guru dan Dosen. 